NBSIR 78-1465

\title{
Urea-Formaldehyde Foam Insulation Subjected to High Humidity Conditions at Elevated Temperatures
}

E. T. Pierce
D. M. Burch

Center for Building Technology National Engineering Laboratory National Bureau of Standards

Washington, D.C. 20234

July 1978

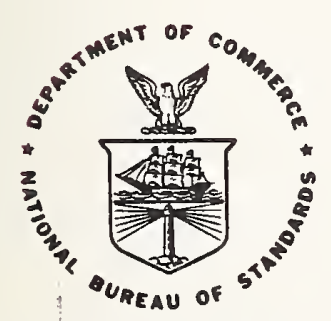

S. DEPARTMENT OF COMMERCE 
NBSIR 78-1465

UREA-FORMALDEHYDE FOAM INSULATION SUBJECTED TO HIGH HUMIDITY CONDITIONS AT ELEVATED TEMPERATURES

E. T. Pierce

D. M. Burch

Center for Building Technology National Engineering Laboratory National Bureau of Standards Washington, D. C. 20234

July 1978

U.S. DEPARTMENT OF COMMERCE, Juanita M. Kreps, Secretary Dr. Sidney Harman, Under Secretary Jordan J. Baruch, Assistant Secretary for Science and Technology NATIONAL BUREAU OF STANDARDS, Ernest Ambler, Director 

UREA-FORMALDEHYDE FOAM INSULATION SUBJECTED

TO HIGH-HUMIDITY CONDITIONS AT ELEVATED TEMPERATURES

by

E. T. Pierce and D. M. Burch

ABSTRACT

Cured specimens of urea-formaldehyde foam insulation from four major manufacturers were exposed to high-humidity conditions at two moderately elevated temperatures in a temperature and humidity chamber. These conditions were $40^{\circ} \mathrm{C}\left(104^{\circ} \mathrm{F}\right)$ at $92 \% \mathrm{rh}$ and $50^{\circ} \mathrm{C}\left(122^{\circ} \mathrm{F}\right)$ at $92 \% \mathrm{rh}$. The occurrence of moisture absorption, shrinkage, weight loss, and crumbling of the specimens during the exposure periods was examined.

Key Woṛds: Insulation properties; moisture in insulation; shrinkage of foam insulation; urea-formaldehyde foam insulation. 


\section{CONTENTS}

Page

ABSTRACT .

1. Introduction.

2. Experimental Procedure.................................... 2

3. Properties of the U-F Foam Insulations....................... 6

4. Experimental Results................................... 7

5. Conclusions........................................... 13

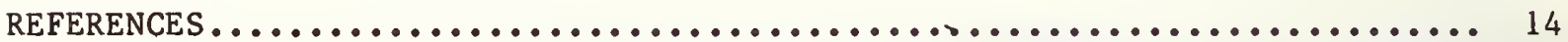




\section{UREA-FORMALDEHYDE FOAM INSULATION SUBJECTED \\ TO HIGH-HUMIDITY CONDITIONS AT ELEVATED TEMPERATURES}

by

E. T. Pierce and D. M. Burch

1. INTRODUCTION

The costs of fuels for space heating of residential buildings have been increasing at a rapid rate. As a result, home owners recently have become interested in reducing the heating energy requirement for their homes by installing thermal insulation in walls, ceilings, and floors. A common method used to install insulation in an uninsulated cavity wall is to drill holes in the top and bottom of each wall cavity and then to inject either a loose-fill or wet-foam material into the cavities of the walls.

A material used to retrofit exterior cavity walls and ceilings is urea-formaldehyde foam insulation. As a building insulation, urea-formaldehyde-based foam is generated on-site using portable equipment to foam a partially polymerized urea-formaldehyde-based resin which then reacts chemically (cures) in place. Three major ingredients are used in the generation of the foam: urea-formaldehyde-based resin, a surfactant (generally called a foaming agent) which includes an acid catalyst or hardening agent, and air. A wet foam is dispersed from the apparatus through a flexible hose into the wall cavity. A chemical reaction between the resin and the hardening agent begins to take place immediately. Initial curing of the foam is reported to begin within one minute. Complete curing of the foam, however, usually requires several weeks. After the foam has cured and dried, it is reported to have good insulating properties due to the many small air pores within its cellular structure [1]*.

The National Bureau of Standards recently conducted an extensive literature survey [1] on urea-formaldehyde foam to assess its thermal and acoustical properties. This report identified two possible problem areas with regard to the use of ureaformaldehyde foam as a thermal insulation in cavity walls and ceilings. These possible problem areas include long-term shrinkage of the foam after it has cured, and the effect of high-humidity conditions at elevated temperatures on the performance of the foam.

In a recent test [2] carried out at a commercial laboratory, cured urea-formaldehyde foam specimens were exposed for 10 days to a near-saturated condition (95 to $100 \% \mathrm{rh}$ ) at an elevated temperature of $70^{\circ} \mathrm{C}\left(158^{\circ} \mathrm{F}\right)$. At the end of the test period, the specimens exhibited a $9.6 \%$ weight loss and a linear shrinkage of approximately $30 \%$. It was further reported that the specimens had warped severely, were friable and very powdery, and could not be handled.

* See references at end of paper. 
The purpose of the present study was to investigate the effects of high-humidity conditions at moderate temperatures on the physical characteristics of urea-formaldehyde foam. The original plan was to expose cured foam specimens to high-humidity conditions at $20,30,40$, and $50^{\circ} \mathrm{C}$. The 20 and $30^{\circ} \mathrm{C}$ conditions would be representative of residential applications, whereas the 40 and $50^{\circ} \mathrm{C}$ conditions would not. Work for the 40 and $50^{\circ} \mathrm{C}$ conditions was completed. However, due to conflicts* with other research efforts, work was not carried out for the 20 and $30^{\circ} \mathrm{C} \mathrm{con-}$ ditions. While the results of this report are not indicative of urea-formaldehyde foam performance in residential applications, the report does provide physical performance data for the foam at 40 and $50^{\circ} \mathrm{C}$ conditions. The properties investigated include weight loss, moisture absorption, shrinkage, and fissuring. The test procedure is documented.

\section{EXPERIMENTAL PROCEDURE}

To obtain a variety of specimens of urea-formaldehyde (U-F) foam, four major manufacturers were contacted, and foam from these manufacturers was injected into wooden enclosures. In two cases, the manufacturer's personnel did the foaming. In the other two cases, foaming was carried out by local contractors with the manufacturer's knowledge. The enclosures were then stored in the laboratory, which was maintained at approximately $23^{\circ} \mathrm{C}\left(73.4^{\circ} \mathrm{F}\right)$ and $40 \% \mathrm{rh}$, for approximately one month in order to permit the injected foams to cure. Specimens of each of the foams were then removed and exposed to the same ambient conditions for a period of ten days to permit further curing to take place. Specimens of the insulations were then placed in a temperature and humidity chamber for a 7-week exposure period at $50^{\circ} \mathrm{C}$ $\left(122^{\circ} \mathrm{F}\right)$ and $92 \% \mathrm{rh}$. Other specimens, which had been kept in the laboratory during the 7-week interval, were placed in the temperature and humidity chamber and were given a 14 -week exposure period at $40^{\circ} \mathrm{C}\left(104^{\circ} \mathrm{F}\right)$ and $92 \% \mathrm{rh}$. Changes in weight, dimension, and appearance were periodically observed and recorded during both the exposure periods. Details of this procedure are described in the following paragraphs.

The wooden enclosures consisted of $1.22 \mathrm{~m}$ ( $4 \mathrm{ft}$ ) high wall cavities fabricated from two nominally $2 \times 4$ studs placed $0.406 \mathrm{~m}$ (16 in) on center with $0.635 \mathrm{~cm}$ ( $1 / 4$ in) plywood attached to the front and back. A $2 \times 4$ plate was placed at the top and the bottom. A photograph of several of the wooden enclosures is shown in Figure 1.

Three of the suppliers used a hose-insertion technique to inject the foam into the wooden enclosure. They inserted a hose for dispersing the foam into the cavity of the enclosure and then gradually withdrew the hose as the cavity was filled with foam. One manufacturer's representative simply squirted the foam from the top of the cavity without inserting the hose. After the cavities were filled, the excess foam was partly struck off with the $2 \times 4$. top plate. The top plate was then fastened across the top of the wooden enclosure. Light compression of the foam helped assure an initially full cavity.

* The temperature and humidity chamber used to condition the specimens belonged to another organizational unit of NBS. Tests could not be perfomed at the 20 and $30^{\circ} \mathrm{C}$ conditions because the temperature and humidity chamber was needed for other research studies. 


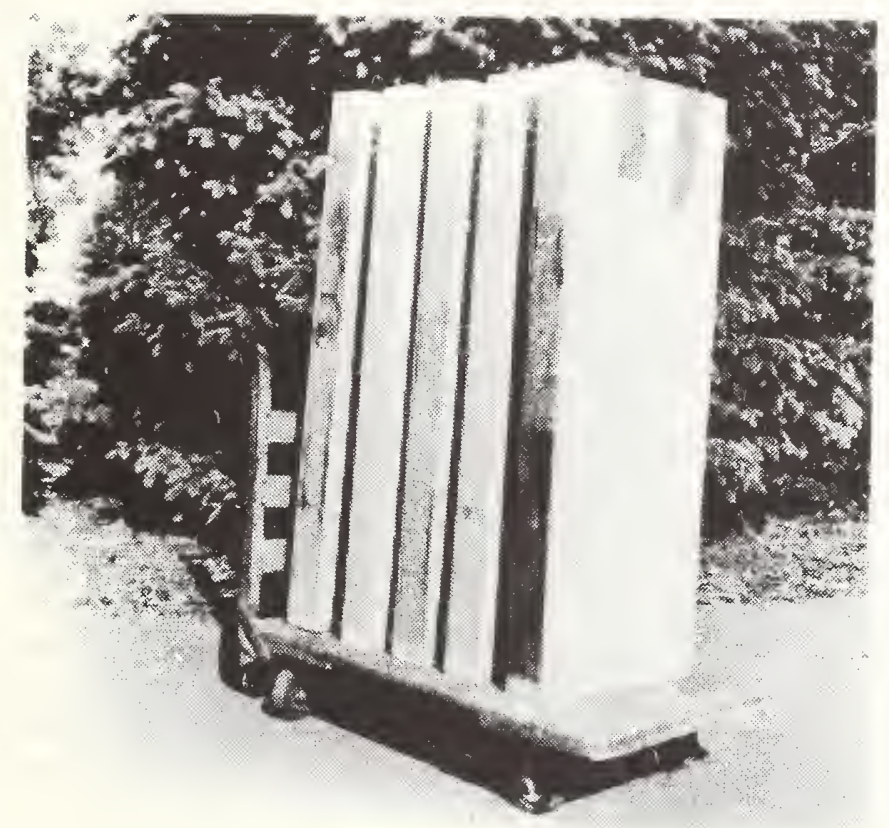

Figure 1. Wooden enclosures. 
After the foaming process was completed, the wooden enclosures were placed in a vertical (upright) position for approximately one month in the laboratory, which was maintained at approximately $23^{\circ} \mathrm{C}\left(73.4^{\circ} \mathrm{F}\right)$ and $40 \% \mathrm{rh}$. The purpose of this onemonth conditioning period for the installed U-F foam insulations was to permit the foam insulations to cure at rates consistent with typical cavity-wall applications. During the curing process, the U-F foam loses moisture to adjacent materials or air spaces. The rate of the curing depends on the rate at which moisture is transferred, which in turn depends on the water-vapor transmission characteristics of the materials comprising the cavity. After U-F foam reaches a dry density of approximately $11 \mathrm{~kg} / \mathrm{m}^{3}\left(0.7 \mathrm{lb} / \mathrm{ft}^{3}\right)$, it is generally considered to have reached a cured state.

One of the wooden enclosures was weighed periodically during the curing period. After 35 days, the wooden enclosure stopped losing weight. At this point, the calculated density of the foam determined from the volume of the wooden enclosure and the weight of the foam was very nearly equal to the dry density of foam. These results suggest that curing of the foam within the wooden enclosure took place in approximately 35 days.

After the insulation was cured in the wooden enclosures, a plywood panel was removed from each of the wooden enclosures and the linear shrinkage in the height and width directions was measured. Next, three large pieces, approximately $23 \times 28 \mathrm{~cm}$ ( $9 \times 11$ inches), were cut out with a bread knife from the U-F insulation contained in each of the wooden enclosures. Differences in.fragility or coherence were observed. The insulation from some of the wooden enclosures could be cut neatly, while that from others was very fragile and tended to fracture when cut.

The three specimens from each of the wooden enclosures were then placed in a cardboard carton and stored at ambient conditions of approximately $23^{\circ} \mathrm{C}\left(73.4^{\circ} \mathrm{F}\right)$ and $40 \%$ rh for six days. The purpose of the second conditioning period was to permit additional curing of the specimens to take place. Shrinkage was not measured during this period.

Test specimens of final size were then cut from the larger specimens and stored for an additional four days. The small specimens were first cut about $1 \mathrm{~cm} l$ larger in width and height than the desired final size. Thin layers were then shaved off until the final size was reached. An attempt was made to produce final specimens with square sides and flat surfaces in the direction of height and width. The thickness of the specimens was not altered from the thickness as installed. The size of the final specimens for test was approximately $10 \times 12 \times 9 \mathrm{~cm}(3.9 \times 4.7 \times 3.5$ in).

Specimens were then placed in a temperature and humidity chamber (see Figure 2) and exposed to $50^{\circ} \mathrm{C}\left(122^{\circ} \mathrm{F}\right)$ and $92 \%$ rh for a 7 -week period. Shrinkage, weight loss, and appearance of the specimens were periodically observed and recorded. Shrinkage and weight loss were also observed for control specimens of the four insulations which were not placed in the temperature and humidity chamber but were instead exposed to laboratory conditions of $23^{\circ} \mathrm{C}\left(73.4^{\circ} \mathrm{F}\right)$ and $40 \% \mathrm{rh}$. Differences in physical performance of the two control groups would be due to differences in the ambient conditions to which the two groups were exposed.

Other specimens from the four manufacturers, which had been exposed to laboratory conditions of $23^{\circ} \mathrm{C}\left(73.4^{\circ} \mathrm{F}\right)$ and $40 \%$ rh during the 7 -week period, were then placed in the temperature and humidity chamber and exposed to $40^{\circ} \mathrm{C}\left(104^{\circ} \mathrm{F}\right)$ and $92 \%$ rh for 


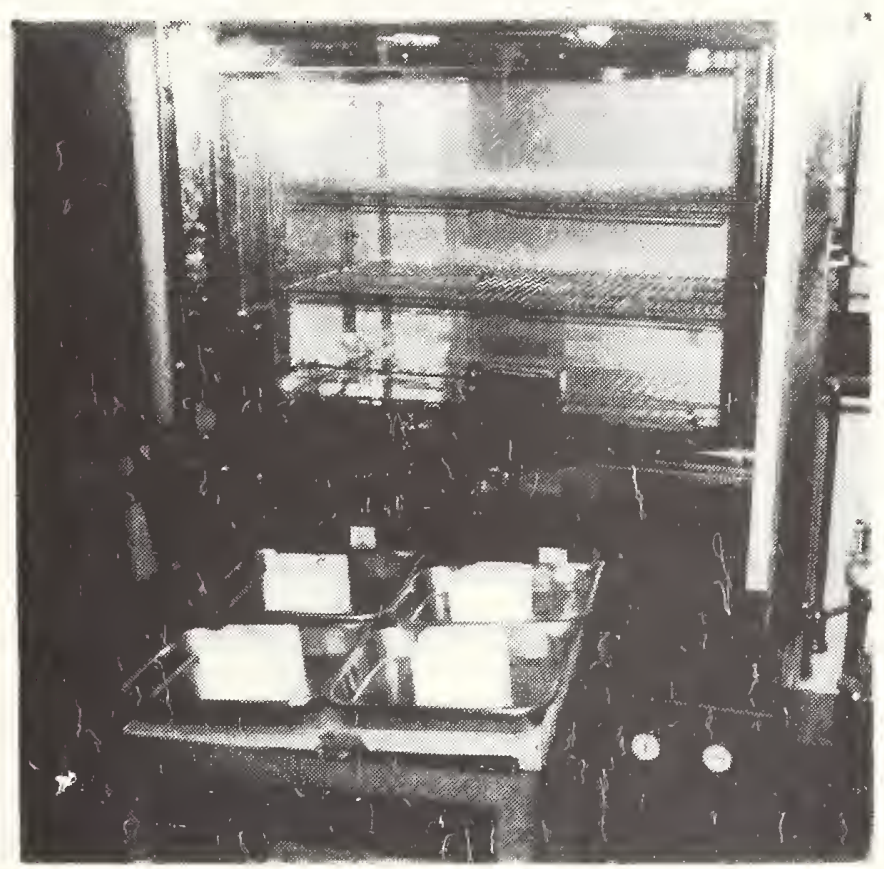

Figure 2. U-F foam specimens ready to be placed
in temperature and humidity chamber. 
a 14-week period. As in the case of the previous test, shrinkage, weight loss, and appearance of the foam specimens were observed and recorded.

\section{PROPERTIES OF THE U-F FOAM INSULATIONS}

The wet densities as foamed, the dry densities as tested, the curing times in the wooden enclosures, and the observed shrinkages during this curing process for the four foam insulations are given in Table 1.

TABLE 1. PROPERTIES OF U-F FOAM INSULATIONS

\begin{tabular}{|c|c|c|c|c|}
\hline $\begin{array}{c}\text { Manufacturer } \\
\text { Type }\end{array}$ & $\begin{array}{l}\text { Wet Density } \\
\text { as }{ }^{3} \text { Foamed } \\
\mathrm{kg} / \mathrm{m}^{3}\left(1 \mathrm{~b} / \mathrm{ft}^{3}\right)\end{array}$ & $\begin{array}{l}\text { Dry Density } \\
\text { as Tested } \\
\mathrm{kg} / \mathrm{m}^{3}\left(1 \mathrm{~b} / \mathrm{ft}^{3}\right)\end{array}$ & $\begin{array}{c}\text { Curing Time in } \\
\text { Wooden Enclosure } \\
\text { days }\end{array}$ & $\begin{array}{l}\text { Shrinkage } \\
\text { During Cure } 1 / \\
\quad \%\end{array}$ \\
\hline A & $40(2.5)$ & $8.1(0.51)$ & 24 & 2.0 \\
\hline B & $45(2.8)$ & $16.8(1.05)$ & 38 & 2.7 \\
\hline $\mathrm{C}$ & $58(3.6)$ & $16.1(1.01)$ & 39 & 2.4 \\
\hline \multirow[t]{2}{*}{$\mathrm{D}$} & $51(3.2)$ & $12.3(0.77)$ & 44 & 2.5 \\
\hline & & & $\mathrm{AV}^{2}$ / & $=2.5$ \\
\hline
\end{tabular}

The wet densities of the foams were determined by dividing the weight of the insulation in the enclosure by the volume of its cavity. The dry density for materials as tested was determined by dividing the weight of the specimens by their volumes.

Foams B, C and D were cured in the wooden enclosure for more than 35 days, which is the estimated curing time based on periodic weighing during the curing process. Foam A was cured in the wooden enclosure for only 24 days, which is 11 days less than the estimated curing time. Therefore, at the time of cutting out specimens from the insulation in the wooden enclosure, foam A may not have reached a cured state. Since specimens of foam A, after being removed from the wooden enclosure, were conditioned for an additional 10-day period in the laboratory air and attained a dry density of $8.1 \mathrm{~kg} / \mathrm{m}^{3}\left(0.51 \mathrm{lb} / \mathrm{ft}^{3}\right)$, it is likely that foam $\mathrm{A}$ was at a cured state at the time of the exposure tests in the chamber.

The linear shrinkage that occurred when the specimens were cured in the wooden enclosures ranged between 2.0 and $2.7 \%$. The $2.0 \%$ figure for specimen $A$ is less than the other specimens, perhaps because this specimen experienced a shorter curing period. Neglecting foam A, the average amount of linear shrinkage observed during the curing process was found to be $2.5 \%$. 


\section{EXPERIMENTAL RESULTS}

\subsection{4-WEEK EXPOSURE TEST* AT $40^{\circ} \mathrm{C}\left(104^{\circ} \mathrm{F}\right)$}

A plot of the relative weight gain of the four specimens placed in the temperature and humidity chamber as a function of time is given in Figure 3. The relative weight gain $(\phi)$ is defined by the relations:

$$
\phi=\left(W-W_{i}\right) / W_{i} \text {. }
$$

Here $W$ and $W_{i}$ are the current weight and initial weight of the specimens, respectively. Note that all the specimens gained weight after being placed in the temperature and humidity chamber. This weight gain was attributed to the acquisition of moisture by the specimens. From the third to the fourteenth week, the specimens tended to lose weight. It was hypothesized that this latter weight loss was due to a chemical reaction involving the acquired moisture and constituent(s) of the specimens.

After the specimens were removed from the temperature and humidity chamber, the weight of the specimens declined markedly as they reached equilibrium with the ambient conditions of the laboratory $\left(23^{\circ} \mathrm{C}\left(73.4^{\circ} \mathrm{F}\right)\right.$ and $\left.40 \% \mathrm{rh}\right)$. Note that the final weight of the specimens after being removed from the chamber was seen to be less than the initial weight of the specimens.

The test results for the 14 -week $40^{\circ} \mathrm{C}\left(104^{\circ} \mathrm{F}\right)$ exposure test are summarized in Table 2. The linear shrinkage for the various $U-F$ foam insulations is given in column 3. After the fourth week, specimens B, C and D began to fissure and fall apart. It was therefore not possible to record linear shrinkage for these specimens after 4 weeks. The specimens of foam A did not fissure and fall apart during the exposed period. Photographs showing the condition of the specimens placed in the chamber and those not placed in the chamber are given in Figure 4. While placed in the temperature and humidity chamber, specimen A underwent a linear shrinkage of $5.1 \%$ in addition to the $2.0 \%$ shrinkage observed during the curing process.

The average linear shrinkage of the control specimens exposed to ambient conditions of $23^{\circ} \mathrm{C}\left(73.4^{\circ} \mathrm{F}\right)$ and $40 \% \mathrm{rh}$ during the 29 -week period was only $1.6 \%$. In addition, none of the control specimens crumbled and fell apart.

* This exposure test was conducted after the 7 -week exposure test at $50^{\circ} \mathrm{C}\left(122^{\circ} \mathrm{F}\right)$. It is presented first because weight changes of the specimens were monitored on a weekly basis, permitting a more detailed discussion of the processes taking place in the temperature and humidity chamber. 


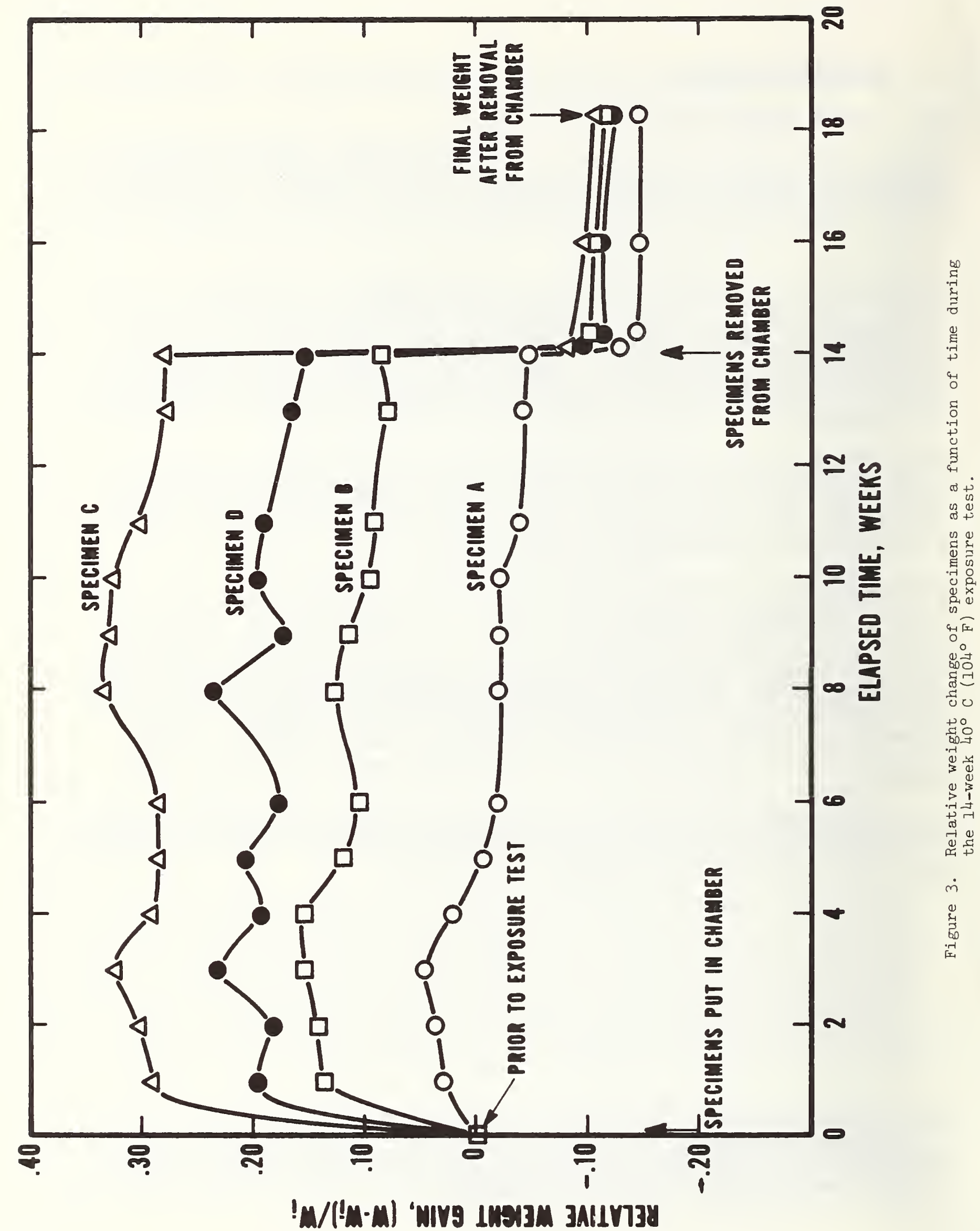



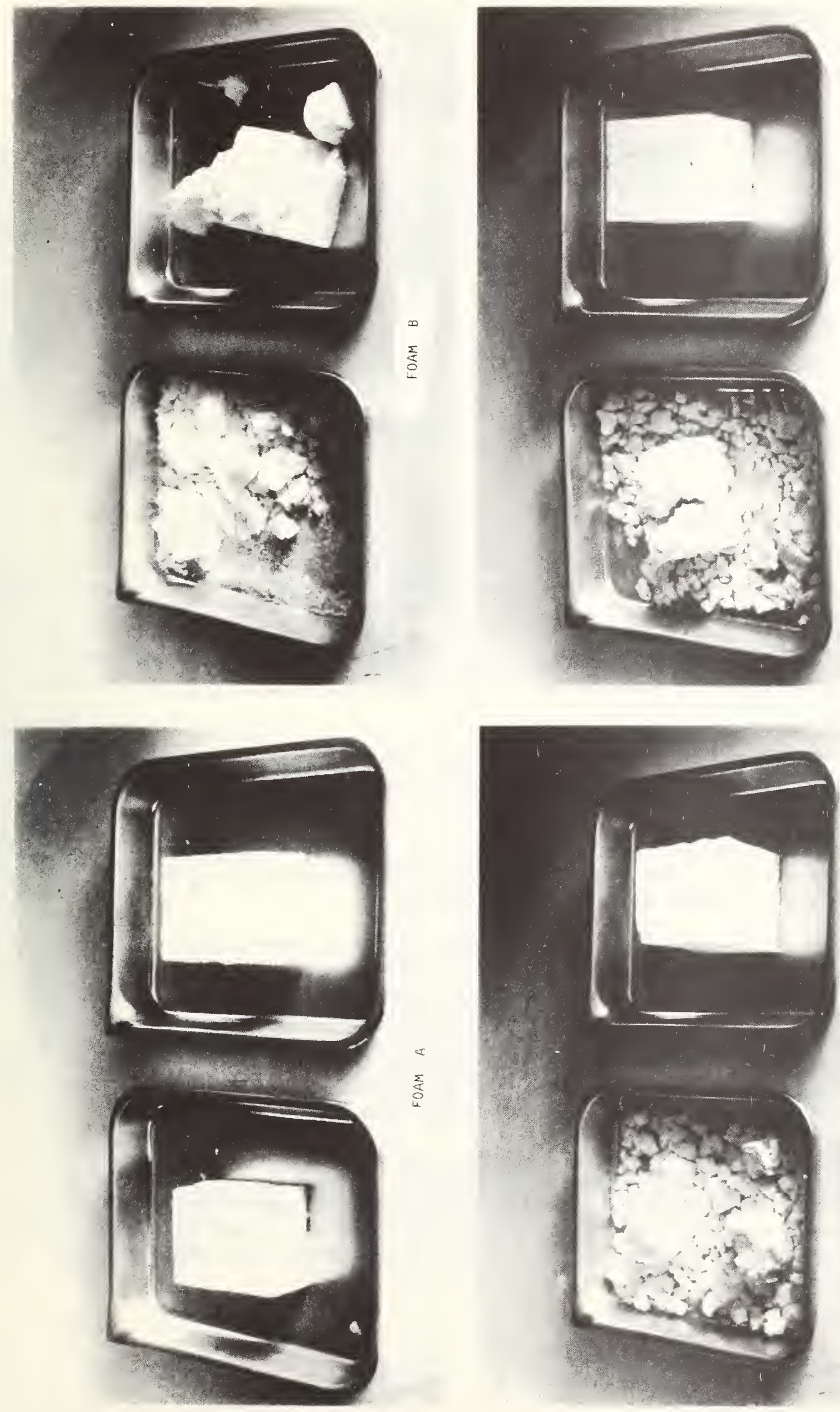
TABLE 2. SUMMARY OF TEST RESULTS FOR 14 -WEEK $40^{\circ} \mathrm{C}\left(104^{\circ} \mathrm{F}\right)$ EXPOSURE TEST

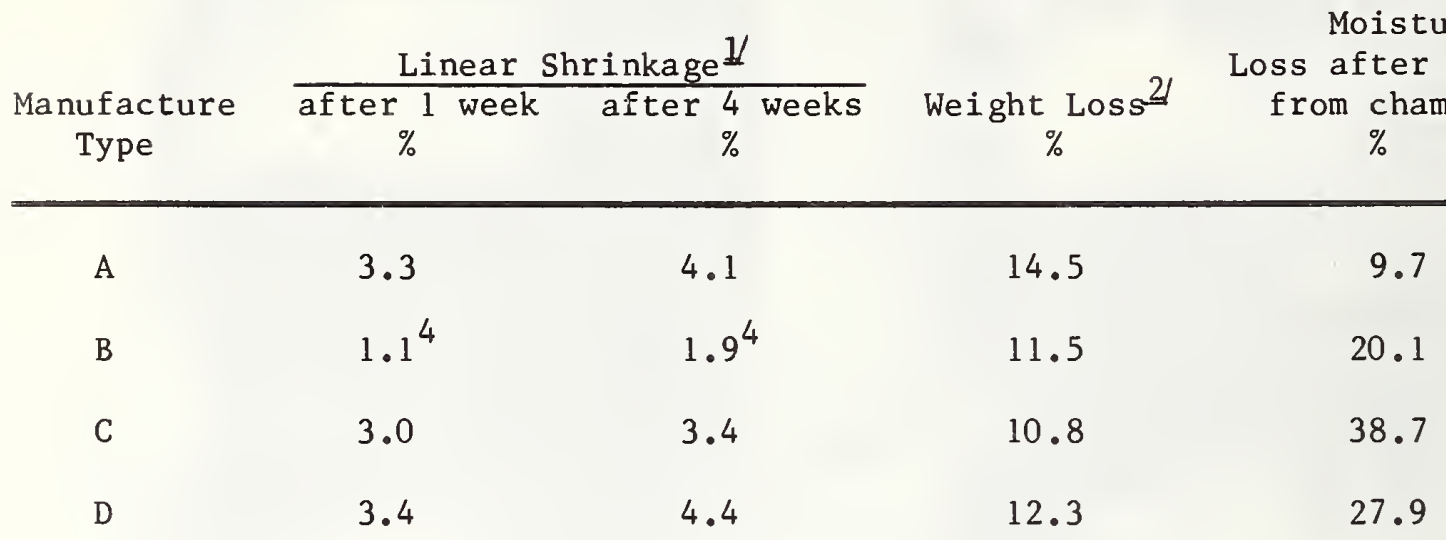

1 Average of linear shrinkage in the length, width, and thickness directions.

2f $\left(w_{i}-w_{f}\right) / w_{j}$, where $w_{i}=$ initial weight of specimen prior to exposure test and $\mathrm{W}_{\mathrm{f}}{ }^{1}$ is the final weight of the specimen after it was removed from chamber and reached equilibrium with ambient air at approximately $23^{\circ} \mathrm{C}\left(73.4^{\circ} \mathrm{F}\right)$ and $40 \% \mathrm{rh}$.

$\underline{3 j}\left(\mathrm{~W}_{\mathrm{z}}-\mathrm{W}_{\mathrm{f}}\right) / \mathrm{W}_{i}$, where $\mathrm{W}_{\mathrm{z}}=\mathrm{final}$ weight of specimen while still in chamber. $W_{i}$ and $W_{f}$ are as above. It is assumed that this weight loss results from reduced moisture content.

4) Shrinkage in width direction only. Shrinkage in other directions could not be measured because of the physical condition of the specimen.

Therefore, it was concluded that the combination of moderately elevated temperatures and high humidity conditions at $40^{\circ} \mathrm{C}\left(104^{\circ} \mathrm{F}\right)$ was the cause of the crumbling and fissuring of the specimens placed in the chamber.

The percentage weight losses for the specimens placed in the chamber are given in column 4 of Table 2. The weight loss for each specimen was determined by taking the difference between the initial weight of a specimen and its final weight after being removed from the chamber and reaching equilibrium with ambient air at $23^{\circ} \mathrm{C}$ $\left(73.4^{\circ} \mathrm{F}\right)$ and $40 \% \mathrm{rh}$. Note that the percentage weight loss for all the specimens does not differ significantly. The average weight loss is $12.3 \%$. On the other hand, the weight loss for the control specimens exposed to ambient conditions $23^{\circ} \mathrm{C}\left(73.4^{\circ} \mathrm{F}\right)$ and $40 \% \mathrm{rh}$ for a 16 -week period ranged between 4.2 and $5.6 \%$.

The percentage of moisture in the specimens which was lost when they were removed from the chamber is given in column 5 of Table 2. This amount of moisture is assumed to be due to the differences between the equilibrium moisture contents for the separate exposure conditions. Note that specimen A, which did not fissure and fall apart, lost much less moisture after being removed from the oven than the other specimens. 


\subsection{7-WEEK EXPOSURE TEST AT $50^{\circ} \mathrm{C}\left(122^{\circ} \mathrm{F}\right)$}

For this exposure test, specimens of foam insulations B, C and D began to fissure after the second week. A photograph showing the condition of the test and control specimens at the end of the 7-week exposure period is given in Figure 5. Note that as in the case of the previously discussed 14-week exposure test, specimen A did not fissure and fall apart.

The test results for the 7 -week exposure test at $50^{\circ} \mathrm{C}\left(122^{\circ} \mathrm{F}\right)$ are summarized in Table 3. The average linear shrinkage at the end of the second week for this exposure test was approximately the same as the amount observed at the end of the fourth week for the 14 -week exposure test at $40^{\circ} \mathrm{C}\left(104^{\circ} \mathrm{F}\right)$. The percentage weight losses tended to be slightly lower than values for the 14-week exposure test at $40^{\circ} \mathrm{C}\left(104^{\circ} \mathrm{F}\right)$. As in the case of the other exposure test, the moisture loss for specimen $A$ after it was removed from the chamber was much less than that for the other specimens.

TABLE 3. SUMMARY OF TEST RESULTS FOR THE 7-WEEK $50^{\circ} \mathrm{C}\left(122^{\circ} \mathrm{F}\right)$ EXPOSURE TEST

\begin{tabular}{|c|c|c|c|c|}
\hline & $\begin{array}{c}\text { Linear } \\
\text { Shrinkage }\end{array}$ & $\begin{array}{l}\text { Linear } \\
\text { Shrinkage }\end{array}$ & & $\begin{array}{l}\text { Moisture } \\
\text { Loss after remova }\end{array}$ \\
\hline $\begin{array}{c}\text { Manufacture } \\
\text { Type }\end{array}$ & $\underset{\%}{\operatorname{after}} 1$ week & after 2 weeks & $\underset{\%}{\text { Weight Loss } 21}$ & $\underset{\%}{\text { from chamber }}$ \\
\hline
\end{tabular}

\begin{tabular}{ccccc}
\hline A & 3.9 & 4.9 & 15.6 & 3.6 \\
B & 2.0 & 4.0 & 10.5 & 9.1 \\
C & 2.9 & 3.6 & 11.0 & 18.1 \\
D & 3.1 & 4.6 & 11.9 & 18.8 \\
& & $A v=4.3$ & &
\end{tabular}

If Average of linear shrinkage in the length, width, and thickness directions.

2/ $\left(W_{i}-W_{f}\right) / W_{i}$, where $W_{i}=$ initial weight of the specimen prior to exposure test and $W_{f}$ is the final weight of the specimen after it was removed from the chamber and reached equilibrium with ambient air at approximately $23^{\circ} \mathrm{C}\left(73.4^{\circ} \mathrm{F}\right)$ and $40 \% \mathrm{rh}$.

3/ $\left(W_{z}-W_{f}\right) / W_{i}$, where $W_{z}=$ final weight of specimen while still in chamber. $W_{i}$ and $w_{f}$ are as above. 'It is assumed that this weight loss results from reduced moisture content. 

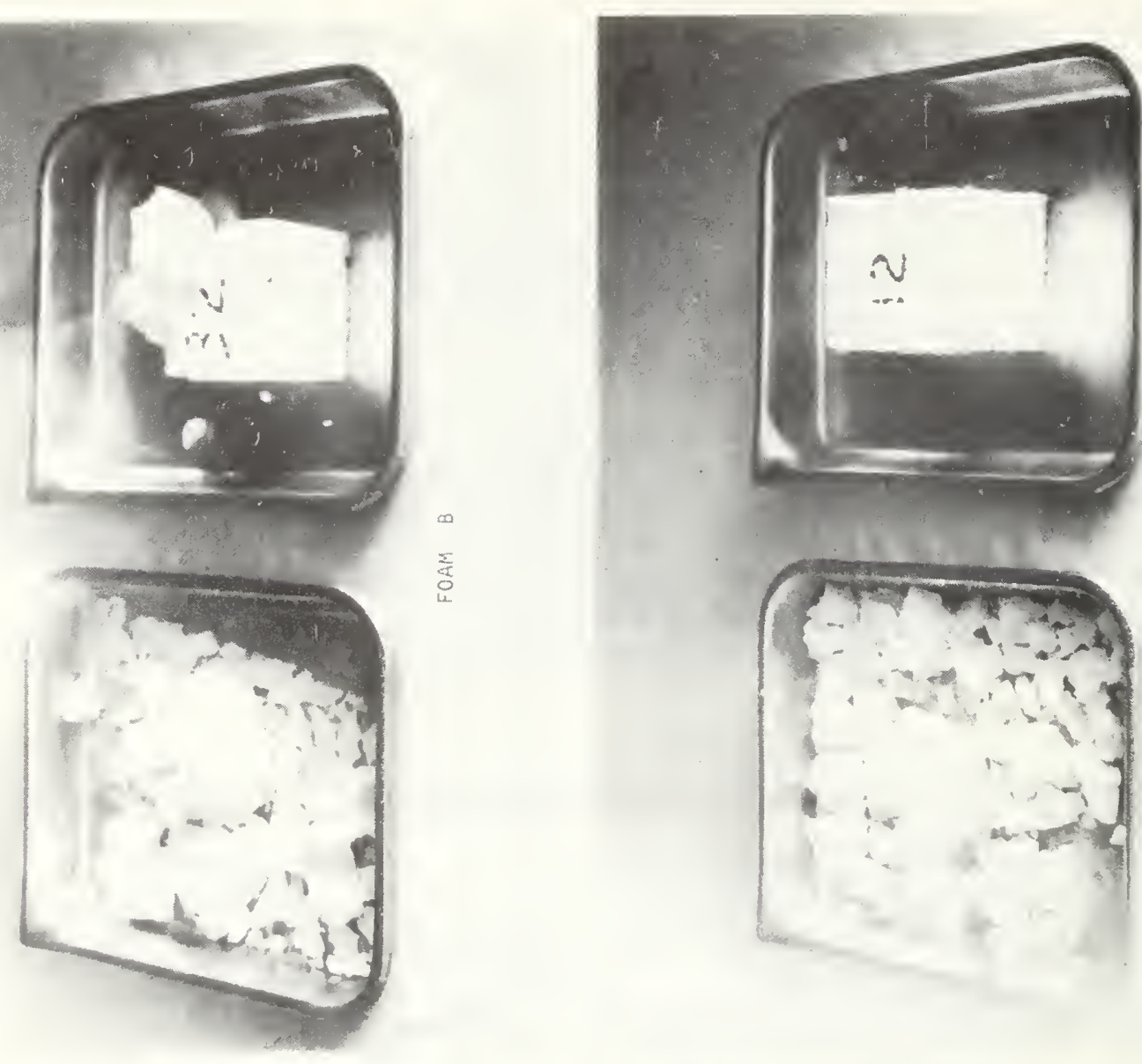

2
0
0
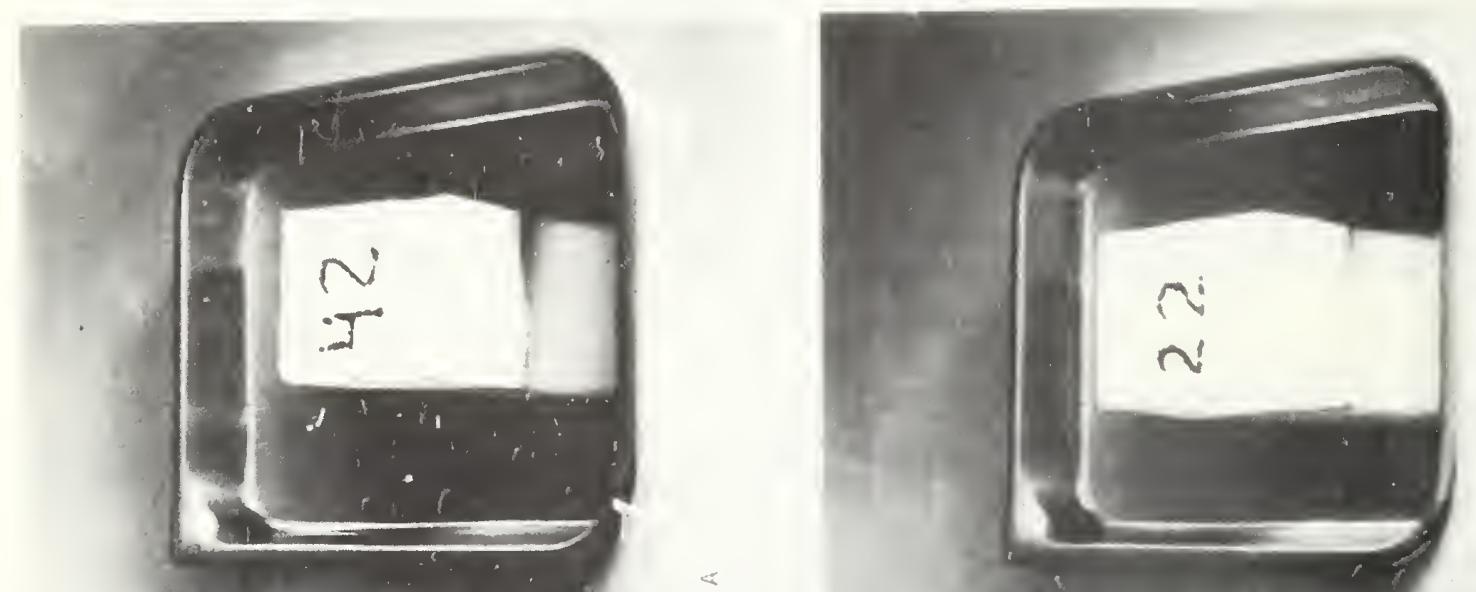

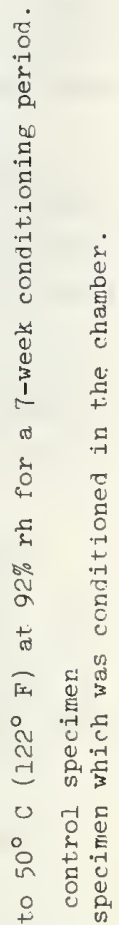
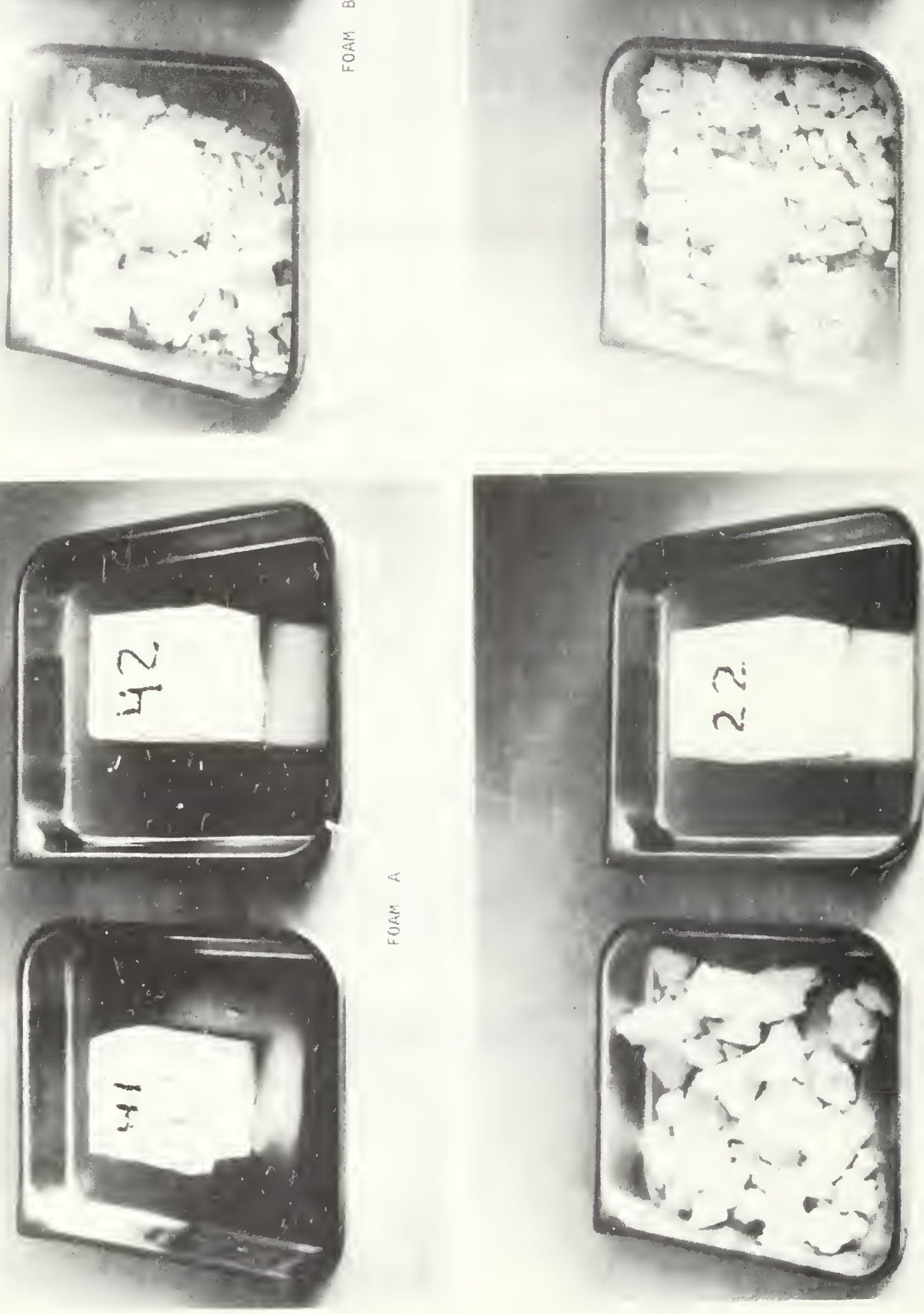

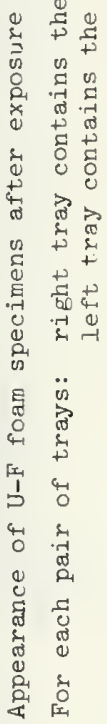




\section{CONCLUSIONS}

Urea-formaldehyde foam from four major manufacturers was cured in wooden enclosures and underwent a linear shrinkage of approximately $2.5 \%$. Specimens from these four foams were exposed in a temperature and humidity chamber for a 14-week period at $40^{\circ} \mathrm{C}\left(104^{\circ} \mathrm{F}\right)$ and $92 \% \mathrm{rh}$, and other specimens for a 7 -week period at $50^{\circ} \mathrm{C}\left(122^{\circ} \mathrm{F}\right)$ and $92 \% \mathrm{rh}$. For both exposure tests, three out of four of the specimens fissured and fell apart. The specimen which did not fissure and fall apart for either exposure test did not take on as much moisture as the other specimens when it was placed in the temperature and humidity chamber. All the specimens underwent linear shrinkage of approximately $4 \%$ during the first two to four weeks of the exposure test. All test specimens also underwent a weight loss between 10 to $16 \%$.

The total linear shrinkage due to the curing process and the exposure test was approximately $6.5 \%$. For cavity wall application, this amount of shrinkage corresponds to a reduction in insulated area of approximately $13 \%$. The uninsulated regions created by the shrinkage constitute high conductance air spaces which will result in increased heat transmission. Another mechanism by which the heat transmission may be increased is air circulation around the insulation.

The experiments did not determine a threshold condition of temperature and humidity below which the U-F foam insulation would not lose its structural form and disintegrate. Neither did the test reveal why one of the four foam insulations did not collapse structurally like the other three. The temperature conditions used in the 7-week and 14-week exposure tests are frequently exceeded in the attic of a residence, but a concurrent relative humidity of $92 \%$ would not be likely to occur after the initial curing period, unless occasional wetting occurred from rain or other causes. Urea-formaldehyde foam insulation of one of the types used in these tests has been periodically observed over a 35-month period in the wall of a test house [3] exposed to natural weather conditions in Washington, D.C. The foam has not collapsed structurally, but it did undergo a linear shrinkage of about $8 \%$ during a 35 -month period.

The results of these tests are not sufficiently comprehensive to provide reliable criteria for the application of urea-formaldehyde foam insulation in buildings, since they do not establish a threshold of temperature and humidity below which structural disintegration will not occur, nor the long-term shrinkage under typical conditions. They do serve as a caution in applying U-F foam insulation in temperature and humidity conditions near those used for the exposure tests. Although one type of foam insulation maintained its structural shape, it did shrink sufficiently to reduce its overall insulating effect significantly.

Further tests are needed to investigate physical and heat transmission characteristics of U-F foam insulation at representative conditions for residential applications, and to determine the causes for variations in physical performances for different brands. If these tests were to show that urea-formaldehyde foam specimens undergo physical degradation when exposed to representative conditions for residential applications, then such a test as outlined in the present report should be incorporated as a test in a performance standard for urea-formaldehyde foam insulation. 


\section{REFERENCES}

1. W. J. Rossiter, R. G. Mathey, D. M. Burch, and E. T. Pierce, Urea-FormaldehydeBased Foam Insulations: An Assessment of Their Properties and Performance, NBS Technical Note 946, July 1977.

2. Urea-Formaldehyde Foam, Report No. 39573, Owens-Corning Fiberglas Corporation, Technical Center, Granville, Ohio, 43023, April 1973.

3. D. M. Burch and C. M. Hunt, Retrofitting an Existing Wood-Frame Residence for Energy Conservation -- An Experimental Study, NBS Interagency Report 77-1274 (July, 1977) and NBS Building Sciences Series BSS 105 (in press). 
NBS.114A (REV. 7.73)

\begin{tabular}{|c|c|c|}
\hline $\begin{array}{l}\text { 1. PUBLICATION OR REPORT NO. } \\
\begin{array}{rlr}\text { NBSIR } 78-1465 & \text { (R) }\end{array}\end{array}$ & $\begin{array}{l}\text { 2. Gov't Accession } \\
\text { No. }\end{array}$ & 3. Recipient's Accession No. \\
\hline \multicolumn{2}{|l|}{ 4. TITLE AND SUBTITLE } & 5. Publication Date \\
\hline \multicolumn{2}{|c|}{$\begin{array}{l}\text { UREA-FORMALDEHYDE FOAM INSULATION SUBJECTED } \\
\text { TO HIGH HUMIDITY CONDITIONS AT ELEVATED TEMPERATURES }\end{array}$} & 6. Performing Organization Code \\
\hline \multicolumn{2}{|l|}{ 7. AUTHOR(S) } & $\begin{array}{l}\text { 8. Performing Organ. Report No. } \\
\text { NBSIR 78-1465 (R) }\end{array}$ \\
\hline \multicolumn{2}{|l|}{ 9. PERFORMING ORGANIZATION NAME AND ADDRESS } & $\begin{array}{l}\text { 10. Project/Task/Work Unit No. } \\
4626141\end{array}$ \\
\hline \multicolumn{2}{|l|}{$\begin{array}{l}\text { NATIONAL BUREAU OF STANDARDS } \\
\text { DEPARTMENT OF COMMERCE } \\
\text { WASHINGTON, D.C. } 20234\end{array}$} & 11. Contract/Grant No. \\
\hline \multirow{2}{*}{\multicolumn{2}{|c|}{ 12. Sponsoring Organization Name and Complete Address (Street, City, State, ZIP) }} & $\begin{array}{l}\text { 13. Type of Report \& Period } \\
\text { Covered } \\
\text { Final }\end{array}$ \\
\hline & & 14. Sponsoring Agency Code \\
\hline
\end{tabular}

15. SUPPLEMENTARY NOTES

16. ABSTRACT (A 200-word or less factual summary of most significant information. If document includes a significant bibliography or literature survey, mention it here.)

Cured specimens of urea-formaldehyde foam from four major manufacturers were exposed to several high-humidity conditions at moderately elevated temperatures in a temperature and humidity chamber. These conditions included $40^{\circ} \mathrm{C}\left(104^{\circ} \mathrm{F}\right)$ at $92 \% \mathrm{rh}$ and $50^{\circ}\left(122^{\circ} \mathrm{F}\right)$ at $92 \% \mathrm{rh}$. The occurrence of moisture absorption, shrinkage, weight loss, and crumbling of the specimens during the exposure periods was examined:

17. KEY WORDS (six to twelve entries; alphabetical order; capitalize only the first letter of the first key word unless a proper name; separated by semicolons)

Insulation properties; moisture in insulation; shrinkage of foam insulation; urea-formaldehyde foam insulation.
18. AVAILABILITY
$\square$ Unlimited

X For Official Distribution. Do Not Release to NTIS

$\square$ Order From Sup. of Doc., U.S. Government Printing Office Washington, D.C. 20402, SD Cat. No.C13

$\square$ Order From National Technical Information Service (NTIS) Springfield, Virginia 22151

\begin{tabular}{|l|l|}
$\begin{array}{l}\text { 19. SECURITY CLASS } \\
\text { (THIS REPURT) }\end{array}$ & 21. NO. OF PAGES \\
UNCL ASSIFIED & 22. Price \\
\hline $\begin{array}{l}\text { 20. SECURITY CLASS } \\
\text { (THIS PAGE) }\end{array}$ & \\
UNCLASSIFIED & USCOMM-DC 29042-P74
\end{tabular}





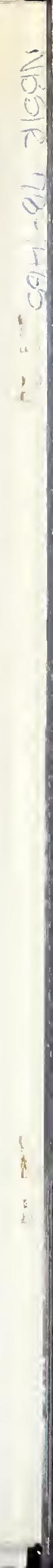

